\title{
IMPLEMENTING EXPERIENTIAL LEARNING IN WRITING CLASS
}

\author{
Ria Yulianti ${ }^{1}$, Achyana Izzatun Nisa'2 \\ ${ }^{1}$ Universitas Ahmad Dahlan, Indonesia \\ ${ }^{2}$ Universitas Ahmad Dahlan, Indonesia
}

\begin{abstract}
The objective of this paper is to describe the implementing of experiential leaning in writing class. Writing is the process of expressing ideas into a good writing and composing the ideas into a proper arrangement. Writing is one of language abilities that is taught in the school. The students should be mastered some text types in writing class, such as descriptive text. Descriptive text is a text which says what a particular thing, person or place is like. In the writing process, the students face some problems in writing, such as finding ideas, developing ideas, and arranging ideas into good composition. In this case, the teacher uses a new method to solve that problems. The teachers use experiential learning to enhance the students' writing. Experiential learning is a learning method where the educators engage the students to learn through experience directly to enhance students' knowledge and skills. It is also called learning by doing. The steps of implementing experiential learning are doing, reflecting, analyzing, generating and application. In descriptive writing, the students can describe the object easily because they use real experience. The students also feel more enthusiasm in learning process. Therefore, hopefully the students can expand their writing in good construction.
\end{abstract}

Keywords: writing, descriptive text, experiential learning

\section{INTRODUCTION}

Writing is expression process of the feelings, ideas, thoughts, or opinions in written form. Writing is one of the skills that should be mastered by the students. In Indonesian curriculum requires the students to be able to write descriptive text. Descriptive text is a text that gives information about particular person, place or thing. A good description is a word picture, the reader can imagine the object, place, or person in his or her mind (Oshima and Hogue, 2007: 61).

Writing is difficult for students because to write a text, students as the writer needs critical thinking to produce ideas, words, sentences, and paragraphs. Jill and Charles (2008: 116) noted that writing is the most difficult skill for many students and even in their mother tongue. In learning writing, there are some difficulties faced by the students such as developing ideas, limitation of vocabulary, and organizing a good text. It is supported by the data from the previous research, Eramona \& Al Hafizh (2014). The researchers claimed that the students did not have ideas to write. They had lack of vocabulary. They also had difficulties in organizing their ideas.

In this paper, the teachers will apply the new learning method in writing descriptive text. Experiential learning is a philosophy and methodology in which educators purposefully with students in direct experience and focused reflection in purposefully in order to increase knowledge, develop skills and clarify valued (Association for Experiential Education, p.2). It is also called learning by doing. Experiential learning also is a powerful way to address individual growth and potential. The students use real object to describe and they can expand their ideas easily. 


\section{LITERATURE REVIEW}

\subsection{The Concept of Writing}

Basically, English consists of oral and written system. Both of them are important, but they are different, it may be stated that only educated people can communicate in written language, because it is very complex one, not only in grammar aspect but also in other factors such as the writer and the reader understand each other. In general, writing is a process in sending message from the writer to the reader. Writing is a process the writer think or a way of thinking which is shared or presented to the reader. Writing is the combination between process and product. Writing is a production of the written word that results in a text but the text must be read and comprehended in order for communication to take place (Celce and Olshtain, 2000: 142). Thus, writing skill is specific ability which help writers put their thoughts into words in a meaningful form and to mentally interact with the message. Writing is not only the activity of setting down some words or sentences into the written language, but also the activity of arranging words into well-organized of writing.

The importance of teaching writing is a basic skill, as important as listening, speaking, and reading. According to Weigle (2001: 4) states that the ultimate goal of learning to write is, for most students, to be able to participate fully in many aspects of society beyond school, and for some, to pursue careers that involve extensive writing. Teaching writing is very important. Through writing, the students can reinforce their grammatical structure, vocabularies, ideas, punctuation and also can explore their creativity and potential to be develop further.

\subsection{The Purpose of Writing}

There are many purposes of writing as follows: To express the writer's feeling: The writer wants to produce and express what she feels or think through the written form (expressive writing). To entertain the readers: The writer intends to entertain the readers through the written form. The writer usually uses aesthetical to entertain the readers (literary writing). To inform the readers: The writer intends to give information of explain something to the readers (informative writing). To persuade the readers: The writer wants to persuade or convince the readers about his opinion or concept or idea (persuasive writing).

\subsection{The Process of Writing}

According to Brown (2000:258), the writing something is a process of writing that involves planning, writing draft, and rewriting again before finally producing a good paper. The first step is planning or pre-writing. This is the process that helps the right words for the expression. It involves the subject to write on and gather of all information about the subject from every available source of information. These form are an important component of the writing process as it deals with the collection of information and the experimentation of ideas.

After finish the gathering the information about the topic, the next step is drafting. This process requires the planning and organizing of the gathered facts. The result of this research should be organized in a logical manner so that the message is conveyed to the reader. So, it needs to present the information in an organized manner and includes the different angle of looking at the subject and an organized draft of the content is one of the key components of writing process.

The next important component of the writing process is revising of the draft. It is the phase to correct the errors in the draft and also think about the ways to improve the writing. The revising is an important constituent of writing as it is about giving a second thought to be writing. 


\subsection{Assessment of Writing}

Assessment is important to determine student achievement in the classroom during the lesson. Teaching and learning process concludes with assessment to determine the success of teaching and learning process in every activity. It can help the teacher to increase the students' motivation. Moreover, McKay (2006: 140) argues that classroom assessment or teacher assessment refers to assessment carried out by teachers in the classroom. The teacher can held assessment for the students' writing ability by giving a task. Then, the teachers give the score of the task by using some guidance, for example using scoring table. According to Oshima and Hogue (2007: 196), to give a score of students writing paragraph should use rubric to score the format, punctuation and mechanic, content, organization and grammar. It can be shown descriptively with the following table. Scoring profile below based on Jacobe et al's (1981) at Weigle (2001: 116).

\begin{tabular}{|c|c|c|c|}
\hline $\begin{array}{c}\text { Aspect of scoring } \\
\text { writing ability }\end{array}$ & Score & Level & Criteria \\
\hline \multirow{4}{*}{ Content } & $30-27$ & Excellent to very good & $\begin{array}{l}\text { - Through development of thesis } \\
\text { - Relevant to assigned }\end{array}$ \\
\hline & $26-22$ & Good to average & $\begin{array}{l}\text { - Limited development of thesis } \\
\text { - Mostly relevant to topic but lacks detail. }\end{array}$ \\
\hline & $21-17$ & Fair to poor & $\begin{array}{l}\text { - Limited knowledge of subject } \\
\text { - Inadequate development of topic }\end{array}$ \\
\hline & $16-13$ & Very poor & $\begin{array}{l}\text { - Does not show knowledge of subject } \\
\text { - Not enough to evaluate }\end{array}$ \\
\hline \multirow{4}{*}{ Organization } & $20-18$ & Excellent to very good & $\begin{array}{l}\text { - Well organized } \\
\text { - Clearly stated/supported } \\
\text { - Cohesive }\end{array}$ \\
\hline & $17-14$ & Good to average & $\begin{array}{l}\text { - Limited supported } \\
\text { - Logical but incomplete sequencing }\end{array}$ \\
\hline & $13-10$ & Fair to poor & $\begin{array}{l}\text { - Non-fluent } \\
\text { - Ideas confused } \\
\text { - Lack logical developing }\end{array}$ \\
\hline & $9-7$ & Very poor & $\begin{array}{l}\text { - Does not communicate } \\
\text { - Not enough to evaluate }\end{array}$ \\
\hline \multirow{4}{*}{ Vocabulary } & $20-18$ & Excellent to very good & $\begin{array}{l}\text { - Effective word/idiom usage } \\
\text { - Appropriate register } \\
\text { - Word form mastery }\end{array}$ \\
\hline & $17-14$ & Good to average & $\begin{array}{l}\text { - Adequate range } \\
\text { - Error of word/ idiom form }\end{array}$ \\
\hline & $13-10$ & Fair to poor & $\begin{array}{l}\text { - Limited range } \\
\text { - Frequent errors of word/ idiom form }\end{array}$ \\
\hline & $9-7$ & Very poor & $\begin{array}{l}\text { - Essentially translation } \\
\text { - Little knowledge of English vocabulary } \\
\text { - Errors word form/ idiom form }\end{array}$ \\
\hline Language Use & $25-22$ & Excellent to very good & $\begin{array}{l}\text { - Effective complex construction } \\
\text { - Word order function } \\
\text { - Articles pronouns } \\
\text { - prepositions }\end{array}$ \\
\hline
\end{tabular}




\begin{tabular}{|c|c|c|c|}
\hline $\begin{array}{l}\text { Aspect of scoring } \\
\text { writing ability }\end{array}$ & Score & Level & Criteria \\
\hline & $21-18$ & Good to average & $\begin{array}{l}\text { - Effective but simple construction } \\
\text { - Several errors of agreement } \\
\text { - Tense, number, articles pronouns, and } \\
\text { preposition but meaning seldom } \\
\text { obscured. }\end{array}$ \\
\hline & $17-11$ & Fair to poor & $\begin{array}{l}\text { - Simple/complex construction } \\
\text { - Frequent errors of negation, agreement, } \\
\text { tense, number, word order/function }\end{array}$ \\
\hline & & & $\begin{array}{l}\text { - Articles pronouns, and preposition } \\
\text { - Meaning confused }\end{array}$ \\
\hline & $10-5$ & Very poor & $\begin{array}{l}\text { - No mastery of constructions } \\
\text { - Dominated by errors } \\
\text { - Does not communicate } \\
\text { - Not enough to evaluate }\end{array}$ \\
\hline \multirow{4}{*}{ Mechanics } & 5 & Excellent to very good & $\begin{array}{l}\text { - Mastery of conventions } \\
\text { - Few errors of spelling, punctuation, and } \\
\text { also capitalization }\end{array}$ \\
\hline & 4 & Good to average & $\begin{array}{l}\text { - Occasional errors of spelling, punctuation, } \\
\text { capitalization } \\
\text { - Meaning not obscured }\end{array}$ \\
\hline & 3 & Fair to poor & $\begin{array}{l}\text { Frequent errors of spelling, punctuation, } \\
\text { capitalization, and paragraphing } \\
\text { - Meaning confused }\end{array}$ \\
\hline & 2 & Very poor & $\begin{array}{l}\text { No mastery of conventions } \\
\text { Dominated by errors } \\
\text { Not enough to evaluate }\end{array}$ \\
\hline
\end{tabular}

\subsection{The Concept of Descriptive Text}

Description is writing about characteristic features of a particular thing. According to Oshima and Hogue (2007: 61), descriptive writing appeals to the senses, so it tells how something looks, feels, smells, tastes, and/ or sounds. Thus, a good description is like a word picture; the reader can imagine the object, place, or person in his or her mind. A writer of a good description is like an artist who paints a picture that can be seen clearly in the mind of the reader. According to Anderson and Anderson in Artami (2013: 9-10) features of a factual description regarded as following generic structure of descriptive paragraph:

a. Identification is general opening statement in the first paragraph or the first sentence that introduces the subject of the description to the audience. In addition, it will make easier the readers to find out the brief details about what, where, or who of the subject.

b. Description is a series of paragraph about the subject where each paragraph usually begins with a topic sentence. The topic sentence previews the details that will be contained in the reminder of the paragraph. Thus, each paragraph should describe one feature of the subject and all paragraphs build the description subject.

\subsection{The Concept of Experiential Learning}

Experiential learning is a philosophy and methodology in which educators purposefully engage with students in direct experience and focused reflection in 
order to increase knowledge, develop skills, and clarify values (Association for Experiential Education, paragraph 2). Experiential learning is a term that has been used to indicate learning through doing (Dean \& Murk, 1998: 3). Experiential learning is the concept of learning that focus on learning through experience or learning by doing. The concept of experiential learning which focuses on problem solving and critical thinking rather than memorization and rote learning.

The following describes the steps that comprise experiential learning as noted by (Haynes, 2007, para. 6 and UC Davis, 2011):

2.6.1 Experiencing/Exploring "Doing"

Students will perform or do a hands-on minds-on experience with little or no help from the instructor. Examples might include: Making products or models, roleplaying, giving a presentation, problem-solving, playing a game. A key facet of experiential learning is what the student learns from the experience rather than the quantity or quality of the experience.

2.6.2 Sharing/Reflecting "What Happened?"

Students will share the results, reactions and observations with their peers. Students will also get other peers to talk about their own experience, share their reactions and observations and discuss feelings generated by the experience. The sharing equates to reflecting on what they discovered and relating it to past experiences which can be used for future use.

2.6.3 Processing/Analyzing "What's Important?"

Students will discuss, analyze and reflect upon the experience. Describing and analyzing their experiences allow students to relate them to future learning experiences. Students will also discuss how the experience was carried out, how themes, problems and issues emerged as a result of the experience. Students will discuss how specific problems or issues were addressed and to identify recurring themes.

\subsubsection{Generalizing "So What?"}

Students will connect the experience with real world examples, find trends or common truths in the experience, and identify "real life" principles that emerged. 2.6.5 Application "Now What?"

Students will apply what they learned in the experience (and what they learned from past experiences and practice) to a similar or different situation. Also, students will discuss how the newly learned process can be applied to other situations. Students will discuss how issues raised can be useful in future situations and how more effective behaviors can develop from what they learned. The instructor should help each student feel a sense of ownership for what was learned.

2.6.6 Using Experiential Learning in Writing Class

Writing is one of a productive skill that is expressed in written mode. Writing is a process of transferring ideas or thoughts from the brain into written language. In other words, writing is sharing thoughts, ideas, and also feelings in written form to the reader. There are many kinds of text that can be used to facilitate the students in writing class, for example descriptive text. Descriptive text is a text for describe person, place ora thing by visual experience.

In writing process, there are some problems or difficulties that are sometimes faced by the students. They are delivering their ideas in a written form, developing ideas, and also getting ideas for their written. The solution is using experiential learning in writing class. Experiential learning provides a real experience for the students. Experiential learning techniques include a rich variety of interactive practices whereby the participants have opportunities to learn from 
their own and each other's experiences, being actively and personally engaged in the process: personal journals, diaries, portfolios, reflective personal essays and thought questions, role plays, drama activities, games and simulations, personal stories and case studies, story-telling, sharing with others, discussions and reflection in cooperative groups.

All of these contain a common element of learning from immediate experience by engaging the learners in the process as whole persons, both intellectually and emotionally. The method is easily adaptable to a wide variety of educational settings, especially to classrooms where project-based and task-based learning already form the core of the curriculum. All classroom activities form a part of student experience. An activity can be done in a group or individually and successfully mined for affective value through questioning techniques and student reflection. The division of the learning process into experiential phases helps sequence the learning activities toward the achievement of the desired learning outcomes. The implementing of experiential learning in writing class:

a. Experiencing/ Exploring "Doing"

The teacher asks the students to visit some historical building in Yogyakarta in group. In this part, the students should experience themselves such as observing what's in the building, the history of the building, the condition of the building, etc. They should record everything that they see in the building.

b. Sharing/ Reflection "What Happened?"

Then, the students will share about the results, reactions and observations with their group. They share their experience and discuss it with their group.

c. Processing/ Analyzing "What's Important?"

The students discuss and analyze the specific information of their experience. The students also relate the experience to the future learning experience.

d. Generating "So What?"

The students will connect the experience with real world examples. For example, in this study is about descriptive text, so the students will try to connect their experience with the descriptive text.

e. Application "Now What?"

In this part, the students will apply what they learned in the experience (and what they learned from past experiences and practice) to a similar or different situation. Here, the teacher asks the students to make a descriptive text in accordance with their experience of visiting the historical building in Yogyakarta.

Example:

Prambanan Temple

Prambanan is the largest Hindu temple compound in Central Java in Indonesia, located approximately $18 \mathrm{~km}$ east of Yogyakarta.

It is characterised by its tall and pointed architecture, typical of Hindu temple architecture, and by the $47 \mathrm{~m}$ high central building inside a large complex of individual temples. It was built around $850 \mathrm{CE}$ by either Rakai Pikatan, king of the second Mataram Dynasty, or Balitung Maha Sambu, during the Sanjaya Dynasty. Not long after its construction, the temple was abandoned and began to deteriorate. Reconstruction of the compound began in 1918. The main building was completed in around 1953. 


\section{METHODS}

This research is library research method. According to Sugiyono (2012: 291), library research related to theoretical studies and other references related to values, cultures and norms develops in the social situation under study, besides library research is very important in doing research, this is due to research will not be separated from the scientific literature. In addition, Nazir (2003: 27) stated that library research is a data collecting technique by conducting a review study of books, literature, notes, and reports that have correlation with the problem solved. Thus, library research is a crucial activity in doing a research. Besides, the researcher can obtain data about similar research or has a correlation with his/her research. The researcher also can utilize information and thoughts related to his/her research.

Library research involves the step-by-step process used to gather information in order to write a paper, create a presentation, or complete a project. The research process itself involves identifying and locating relevant information, analyzing what you found, and then developing and expressing your ideas. These are the same skills you will need on the job when you write a report or proposal. The researchers used secondary sources. Secondary sources are studies by other researchers. They describe, analyze, and/or evaluate information found in primary sources. By repackaging information, secondary sources make information more accessible. A few examples of secondary sources are books, journal and magazine articles, encyclopedias, dictionaries, handbooks, periodical indexes, and reviews, etc.

\section{FINDINGS AND DISCUSSION}

Writing is one of important language skill used by students in English lesson. This reality makes teacher think that writing skill should be mastered by the students.

The teacher can use new method to help students in improving their students' writing skill. Implementing experiential learning can improve the students' writing skill. Experiential learning is a learning process that use the experience of the learners as a method to assist the learner in the teaching and learning process. Implementing experiential learning in writing class can be shown from some researchers. First, the research was conducted by Maharani, Kristiawan and Hayati (2014). It can be concluded that applying experiential learning gave significant effect in writing skill. It can be seen from the students mean score in experiment class was higher (73.20) than students mean score in control class (66.97). Second, the research was conducted by Qoirul (2016). The researcher claimed that the implementation of experiential learning method was improved students' writing skill. The observation result showed that the students become active during teaching learning process. It can be seen from the improvement of students' score from cycle 1 to cycle 2 . The students' percentage who reached KKM in cycle 1 was $55 \%$ up to $100 \%$ in cycle 2 . Third, the research was conducted by McManus and Thiamwong (2015). This study focused on the effects of involving fourth grade students in an experiential learning task that improved the school and required the students to call on community agency, area business, and high school student support. From the qualitative data analysis, it was clear that purposeful writing increased student's enjoyment of writing. Student enjoyed orally presenting their prewriting and these presentations proved to be an effective method for the revision and editing of their written work. The last, the research was conducted by Komalasari (2013). It can be concluded that the experiential learning approach is 
one effective way to make the EFL learners exposed with English. Even though they still made some mistakes, they had obtained the knowledge in the different level. They did not only learn about formula in the sentence making, but they had experienced English and use English as a medium to convey their experiences in their lives.

\section{CONCLUSION}

Experiential learning is a learning process that use the experience of the learners as a method to assist the learner in the teaching and learning process. It is also called learning by doing. The students will be more easily to understand the materials or do their tasks by giving them direct experience not just giving them a theory. In writing skill, the students sometimes feel difficult to begin their writing. They feel hard to develop their thoughts or ideas. Thus, it can be easier for them to start writing if they have a real or direct experience in accordance with their materials or tasks. Experiential learning needs the students' real experience to turn on the students' critical thinking. The students can write their experience in description form. The process of experiential learning in classroom start from the students should go out to get experience. Then, the students share their experience to their friends. After that, the students analyze their information that they get from their experience. Then the students apply their experience in writing form. The students are asked to write a text that connects with their experience. By using experiential learning, the students can enhance their writing skill.

\section{REFERENCES}

Artami, N. R. 2013. Teaching Descriptive Paragraph through PPP Technique to the Eight Grade Students of SMP Dharma Wiweka in Academic Year 2012/2013. TA: FKIP Mahasaraswati Denpasar.

Association for Experimental Education. Retrieved from: http://www.aee.org/. Downloaded in $14^{\text {th }} 2017$ at $14.00 \mathrm{pm}$.

Brown, H. Douglas. 2000. Principles of Language Learning and Teaching. San Francisco: San Francisco State University.

Celce, Marianne \& Murcia Elite Olshtain. 2000. Discourse and Context in Language Teaching. USA: Cambridge University Press.

Eramona, Feradilla. and Al Hafizh, Muhd. 2014. Using The Clustering Technique in Teaching Writing a Descriptive Text to Junior High School Students. Padang: University of Padang.

Gary J, Dean \& Peter J, Murk. 1998. Progress Town Analysis - An Application of the Process Model for Experiential Learning in Adult Education. US: The Educational Resources Information Center (ERIC).

Hadfield, Jill \& Hadfield, Charles. 2008. Introduction to Teaching English. New York: Oxford University Press.

Harmer, Jeremy. 2004. How to Teach English. England: Pearson Education Limited.

Haynes, C. 2007. Experiential learning: Learning by doing.http://adulteducation.wikibook.us/index.php?title=Experiential_Learn ing http://adulteducation.wikibook.us/index.php?title=Experiential Learning -

Learning by Doing_Learning_by_Doinghttp://adulteducation.wikibook.us/ind ex.php?title=Experiential Learning - Learning by Doing 
Komalasari, Adesti. Employing Experiential Learning to Teach Writing for English as a Foreign Language Learners Through a Reflection Project. Universitas Bandar Lampung: International Journal on Education.

Maharani, Silvia., Kristiawan, Muhammad., and Hayati, Amal. 2014. Effect of Experiential Learning Toward Students' Writing Skill at Grade X High School 1 VII Koto Sungai Sariak, Padang Pariaman, West Sumatera. West Sumatra: The Journal of Applied Sciences Research.

McKay, P. 2006. Assessing Young Language Learners. New York: Cambridge University Press.

Nazir, Moh. 2003. Metode Penelitian. Jakarta: Ghalia. Oshima, A., and Hogue, A. 2007. Introduce to Academic Writing. NY: Pearson Education Limited.

Qoirul, Siti. 2016. Improving Students' Writing Recount Text Through Experiential Learning Method at Eight Grade Students of SMP N 1 Balong in Academic Year of 2015/2016. Ponorogo: Muhammadiyah University of Ponorogo.

S. McManus, Michael \& Thiamwong, Ladda. 2015. Enhancing Fourth Grade Students' Writing Achievement through Purposeful Experiential Learning: An Action Research Study. United States: Universal Journal of Educational Research.

Sugiyono. 2012. Metode Penelitian Kuantitatif Kualitatif dan $R \& D$. Bandung: Alfabeta.

Weigle, S. C. 2001. Assessing Writing. UK: Cambridge University Press. 